\title{
The Effect of Communication Strategy Instruction on Saudi EFL Learners' Strategy Use, Speaking Proficiency and Self-Efficacy
}

\author{
Hassan M. Kassem \\ Tanta University, Egypt \& Shaqra University, Saudi Arabia \\ E-mail: hkassem2007@hotmail.com
}

Received: March 25, 2019 Accepted: April 9, 2019 Published: April 11, 2019

doi:10.5296/jsel.v7i1.14649 URL: https://doi.org/10.5296/jsel.v7i1.14649

\begin{abstract}
The current study investigated the effect of communication strategy instruction on Saudi EFL learners' strategy use, speaking proficiency and speaking self-efficacy. Two intact classes of EFL freshmen at Thadiq Sciences and Humanities College, Shaqra University, KSA participated in the study in the first semester of the academic year 2018-2019. They were assigned to an experimental group $(\mathrm{N}=20)$ and a control group $(\mathrm{N}=19)$. A speaking test and a speaking self-efficacy questionnaire were administered to the two groups. Students' oral production and communication strategy use were assessed by independent raters. Independent samples t-tests performed on the pretest mean scores of the two groups showed that they were homogenous in strategy use, speaking proficiency and speaking self-efficacy prior to the treatment. Treatment group students were then taught four communication strategies: circumlocution, approximation, appeal for help, and fillers in the Listening and Speaking 2 (Eng 122) course. The control group received the teaching sequence adopted in the course's textbook which includes no training on communication strategy. Independent and paired samples t-tests revealed that the treatment group outperformed the control group in all dependent variables, hence supporting the positive effect of communication strategy training on strategy use, speaking proficiency and speaking self-efficacy. Pedagogical implications are offered.
\end{abstract}

Keywords: Communication strategy, strategy use, speaking proficiency, speaking self-efficacy, EFL learners 


\section{Introduction}

Language learners have similar problems with speaking in most FL settings. Of all language skills, speaking is the most demanding and complex for FL learners, as it involves different competences and mechanisms (Levelt, Roelofs \& Meyer, 2000). Several reasons have been reported for FL learners' limited speaking proficiency. Speaking, which lacks the characteristics of being private and controllable, is anxiety provoking (Kitano, 2001). Anxiety, which is reported to be high in FL learners, results in learners' abstaining from participating in speaking activities and thus inhibits the development of their speaking proficiency. This debilitative anxiety stems from many sources at the top of which are limited linguistic resources. Limited communicative competence makes learners unwilling to speak in the FL (Williams, 2006). Lack of exposure to the FL outside the classroom in FL settings which are "input poor" (Kouroago, 1993) also contributes to learners' poor speaking proficiency. A further reason is that speaking is the least practiced skill in the FL classroom (Richards, 2008). Researchers have documented over-emphasis on writing to the neglect of speaking in FL settings (Fageeh, 2011; Al-Ghamari, 2004, Al-Nasser, 2015).

Teaching communication Strategies (CSs) has long been proposed for improving FL learners' ability to express themselves orally. CSs are "... strategies that learners use in order to put across meaning when they are sometimes having difficulty because of insufficient competence in the language" (Macaro, 2001: 18). Interest in CSs originated from the fact that the "mismatch between L2 speakers' linguistic resources and communicative intentions leads to a number of systematic language phenomena whose main function is to handle difficulties or breakdowns in communication" (Dornyei \& Scott, 1997, 174). However, the teachability of CSs has long been controversial. Some scholars hold that CSs should not be taught and even question whether they can be taught at all. Others contend that they can be taught and that when mastered they have a good reflection on learners' communicative competence. A large number of scholars therefore conceive of CSs as actions taken by speakers to express meaning in the face of difficulties. CSs can therefore be crucial for FL learners whose linguistic competence does not allow them to communicate effectively without maneuvering.

Regardless of contradictory views about CSs, several renowned researchers maintain that CSs are good for the development of FL learners' competence. Oxford (1990: 49) states that "compensation strategies for production help learners to keep on using the language, thus obtaining more practice". Holding the same view, Macaro (2001: 213) justifies that CSs help competence as "Conversations which flow are likely to generate higher order ideas and therefore richer vocabulary and more complex sentences such that the input the learner receives will be of a better quality". Similarly, Faucette (2001: 6) points out that effective use of CSs leads to extended interaction which means that "learners can receive more input, can stay in the conversation, and develop their ability". Supporting the potential positive effect of CSs on learners' speaking proficiency, particularly fluency, Dornyei (1995: 66) contends that "Training students in communication strategies can improve their fluency along the slogan that language learners should be encouraged to say what they can, rather than retreat silently from what they can't". This is also adopted by Oxford (1990: 49) who assumes that CSs make learners fluent in what they know. Lack of fluency which is characteristic of EFL 
speakers is to a great extent a result of "the underdevelopment of strategic competence" (Dornyei and Thurrell, 1991: 16).

In addition to theoretical contentions such as those mentioned above, research has documented a positive relationship between CS instruction and EFL learners' speaking proficiency. For instance, in a study conducted in the Iranian context by Saeidi and Farshchi (2015), the oral production of 60 EFL junior high Iranian students as measured by T-units significantly improved after they received training on CSs (e.g., circumlocution, time-gaining, approximation, code-switching, and appeal for help). In the Thai context, Kongsom (2016) taught ten CSs to 57 engineering undergraduate students. The instruction had a positive influence on students' reported use of strategies. Students also successfully transferred all ten taught CSs to their utterances in the assessment tasks. In an Arabic context, the effect of CS instruction on Jordanian EFL students' oral performance and strategy use was explored by Bataineh, Al-Bzour and Baniabdelrahman (2017). The interactional communication strategies of approximation, circumlocution, repetition, appeal for help, self-repair, appeal for confirmation, appeal for clarification, and guessing were targeted. Both quantitative and qualitative data revealed that CSs improved both oral performance and strategy use.

\section{Statement of the Problem}

As the case with learners in other EFL settings, researchers have reported poor speaking proficiency among Saudi EFL learners (e.g., Alyan, 2013; Al-Nasser, 2015; Kassem, 2018). Several reasons have been documented for this limited speaking proficiency, all of which seem to apply to most EFL settings. These include limited communicative competence, high levels of speaking anxiety, lack of exposure to the FL outside the classroom, over-emphasis on writing to the neglect of speaking (Rababah, 2005; Fageeh, 2011; Al-Ghamari, 2004, Al-Nasser, 2015). All these factors apply to English program students at the college where the present researcher works (Thadiq Sciences and Humanities College at Shaqra University, KSA). Direct experience with these students reveals several signs of limited speaking proficiency. They show reluctance to speak in English and complain that their competence is too weak to allow them to express themselves in fluent oral English. This is evident in an observation raised by ESL instructors that students cannot communicate with them when they need to talk to them outside the classroom. It happens often that students seek the help of an Arabic-speaking instructor to mediate their communication with ESL instructors. They also show high levels of speaking anxiety. Similar observations about a comparable sample of Saudi college students (English majors at Prince Sattam bin Abdulaziz University) were reported (Kassem, 2018), e.g., poor speaking skills, reluctance to participate in conversations, fear of committing errors, lack of confidence.

The English program offered to the population of the present study includes three courses that are concerned with speaking. These are Listening and Speaking 1 (Eng 112), Listening and Speaking 2 (Eng 122) and Speech Styles (Eng 412). In the first two courses students listen to audio material, answer comprehension questions and speak about a topic relevant to the listening material. In the other course, students are taught to present a speech. In none of these courses students are trained on CSs. Given that students pass these courses and remain 
unable to speak fluent oral English, the researcher thought of including CS instruction in the Listening and Speaking 2 Course as a component that can address their poor speaking proficiency. Mastery of CSs can be of great benefit to students to enable them to overcome their limited resources. For this reason, the researcher planned to teach students some achievement strategies (circumlocution, approximation, appeal for help and use of fillers), rather than avoidance strategies. The ultimate aim of the proposed training was to get students to cope with communication difficulties, not to evade them. More specifically, the study addressed the following questions:

1. What effect does CS instruction have on Saudi EFL learners' strategy use?

2. What effect does CS instruction have on Saudi EFL learners' speaking proficiency?

3. What effect does CS instruction have on Saudi EFL learners' speaking self-efficacy?

\section{Review of Literature}

\subsection{Views of CSs}

Interest in CSs began with Canale-Swain's (1980) inclusion of strategic competence as a major component of their well-known construct of communicative competence. By strategic competence they meant "Verbal and nonverbal strategies that may be called into action to compensate for breakdown in communication due to performance variables or to insufficient competence" (p. 30). Since then, CSs have received increasing popularity under several terms, e.g., communication strategies (Dornyei, 1995), compensation strategies (Oxford, 1990), interaction strategies (Macaro, 2001). CSs have been viewed from different perspectives. That is why there is no consensus as to what CSs are. A perspective mainly concerned with competence is the linguistic perspective. Proponents of this perspective view CSs as devices used to compensate for limited linguistic proficiency. This is reflected in Faerch-Kasper's (1983: 36) definition of CSs as "potentially conscious plans for solving what to an individual presents itself as a problem in reaching a particular communicative goal."

Other researchers, concerned with the interactional aspect of communication, oppose limiting CSs to linguistic problem-management. They extend CSs to include meaning-negotiation and repair mechanisms. Tarone (1980: 420), for instance, conceives of CSs as "tools used in a joint negotiation of meaning where both interlocutors are attempting to agree as to a communicative goal." Building on linguistically and interactionally-oriented visualizations, Dornyei (1995) added stalling devices (e.g., pause fillers and hesitation gambits) since these devices help the speaker to gain time and keep communication going in times of difficulty. In combination, the linguistic perspective, the interactional perspective and Dornyei's perspective led to the inclusion of problem-management, repair mechanisms and stalling devices into CSs.

A completely different visualization of CSs was proposed by psycholinguistic researchers. Unlike the linguistic and interactional perspectives that are product-oriented, the psycholinguistic perspective is mainly concerned with the mental processes underlying strategic language use. Psycholinguistic researchers called for identifying the underlying 
cognitive processes rather than their surface manifestations. They are, therefore, these different visualizations that account for variations in defining CSs (Griffiths, 2004). In the face of these variations, researchers have generally agreed to Bialystock's (1990: 116) statement that "Communication strategies are an undeniable event of language use, their existence is a reliably documented aspect of communication, and their role in second language seems particularly salient."

\subsection{Classification of CSs}

Due to variations in conceptions and orientations, several different taxonomies of CSs have been proposed. Willems (1987) developed a taxonomy where CSs are classified under two main categories. One category encompasses reduction strategies which are used by the speakers to tailor their message to their resources (e.g., message reduction, message replacement, message abandonment). Because these strategies involve avoiding the communication problem instead of trying to cope with it, they affect interaction negatively and are common among low-proficiency learners (Nakatani, 2006: 151). The other category encompasses achievement strategies which speakers use to convey their messages within their limited linguistic resources (e.g., circumlocution, approximation, appeals for assistance). Because these strategies involve working on an alternative plan for reaching the communicative goal by means of whatever resources are available, they are regarded as "good learner" behaviors (Nakatani, 2006: 151). Reflecting on these two types of strategies, Littlemore (2003) asserts that higher proficiency learners tend to employ 'achievement' strategies such as paraphrase and word coinage, while lower proficiency learners tend to employ 'reduction' strategies such as word abandonment and word avoidance, and that the former are more effective.

Perhaps the most well-known and detailed taxonomy of CSs is the one developed by Dornyei and Scott (1997). This classification system considers the linguistic, interactional and psychological perspectives, rendering it very inclusive. The taxonomy is problem-oriented in that strategies are classified according to the problems speakers face and the manner they are managed. Strategies appear under three main headings: direct, indirect and interactional. Direct strategies are the strategies used to provide an alternative meaning (e.g., circumlocution). Listed under indirect strategies are the strategies that facilitate the conveyance of meaning and keep the communication channel open (e.g., pause fillers). Interactional strategies include the strategies used by interlocutors to negotiate meaning (e.g., appeal for help). The researchers, then, relate these three main categories to four types of communication problems: resource deficit, processing time pressure, and own- and other-performance problems. Achievement or compensatory strategies involve compensation for missing knowledge. Dörnyei (1995) provided eleven types of compensatory strategies. These are circumlocution, approximation, use of all-purpose words, word coinage, prefabricated patterns, non-linguistic signals, literal translation, foreignizing, code switching, appeal for help and stalling or time-gaining strategies. What follows is a brief account of the achievement strategies targeted in the present study.

Circumlocution is one of the compensation strategies for overcoming resource deficit 
problems. That is, it is used to make up for gaps in linguistic knowledge. It means "Describing or exemplifying the target object or action" (Dornyei, 1995: 58). A speaker who cannot retrieve the word scissors for example can circumlocute by describing it as 'a tool used for cutting things such as paper and hair'. Approximation is another strategy that helps with resource deficits. It refers to "Using an alternative term which expresses the meaning of the target lexical item as closely as possible" (Dornyei, 1995: 58). An example of approximation is the use of the superordinate term 'bird' for 'owl'. Appeal for help is an interactional strategy used when interlocutors negotiate meaning. Defined by Dornyei (1995: 58), appeal for help means "Turning to the communication partner for help either directly or indirectly (e.g., what do you call...? Or indirectly (e.g., rising intonation, eye contact, puzzled expression)." Using pause fillers is a strategy for coping with processing time pressure. Dornyei (1995: 58) defines it as "Using filling words or gambits to fill pauses and to gain time to think." Stressing the contribution of pause fillers to fluency, Taylor (2002: 171) states that they "facilitate the flow of conversation by giving the speaker time to organize his or her thoughts, maintain or relinquish the floor, expound on an argument, or specify the function of a particular utterance." Also de Bot (1992: 14) stresses that pause fillers are important for nonnative speakers because L2 speech production for L2 speakers is less automatic than speech processing in the L1.

\subsection{The Teachability of CSs}

Whether or not CSs are teachable has been a controversial issue. Some researchers question the teachability of CSs. The strongest opposition to the teachability was voiced by Kellerman (1991: 158) who states that "There is no justification for providing training in compensation strategies in the classroom...teach the learners more language and let strategies look after themselves." Holding this same view, Bialystock (1990: 147) wrote "What one must teach students of a language is not strategy, but language." Accounting for his position, Kellerman (1998: 102) states that "with communication strategies there is no guarantee a) that the strategy will be understood by the interlocutor, b) that the interlocutor can or will actually provide the missing item, and c) that it will be recalled by the learner the next time it is needed". Other researchers have argued that training in CS use is possible and even necessary in order to develop strategic competence in the L2. Dornyei (1995), for instance, strongly maintains that CSs are teachable and that training in them is desirable. He reacts to a claim that strategic competence develops in the speaker's L1 and transfers to L2 or FL by a convincing proposition that if this is accepted, then "we need not teach reading skills because learners can already read in their L1". Added to this theoretical justification, empirical research proved that CSs can be taught successfully (e.g., Abdel Rehim, 2002; Kongsom, 2006; Al-Bzour \& Baniabdelrahman, 2017).

\subsection{Elements Included in the Teaching of CSs}

Several approaches have been proposed to strategy training. Most approaches converge on a number of elements that should be included in training. Awareness raising: Raising students' awareness of strategies is crucial for several reasons. One reason is that it sensitizes students to the strategies already in their repertoire (Dornyei, 1995: 63). Another reason is that 
awareness results in effective application of strategies (Raya, 1998: 20). A third reason is related to strategy maintenance and transfer. Awareness makes strategies stable and transferable to new contexts (Chalmers and Fuller, 1996: 30). Relevant to this is the confirmation of Oxford, Crookall, Cohen, Lavine, Nyikos and Sutter (1990: 199) that "...the more effective language learners use them [strategies] more consciously, more purposefully, and more frequently than do less able students." O'Malley and Chamot (1990: 184) also refer to the importance of strategic awareness, "Students should be apprised of the goals of strategy instruction and should be made more aware of the strategies they are being taught." Modeling: Modeling means demonstrating the strategy with thinking aloud accompanying the demonstration, so students can follow the steps of the strategy. This can be achieved in several ways. That the teacher leads and demonstrates strategy use is one way. That students follow a videotaped demonstration is another. Awareness raising should be followed by modeling. This is inevitable since awareness alone does not necessarily lead to actual use of the strategies. In this same respect, Macaro (2001: 187) alerts, "Just making the learners aware of the existence of the strategies is not going to bring about successful strategy use. They need to be shown explicitly and repeatedly the strategies which they can try in order to achieve better learning. Thus, awareness raising should be followed by modeling." Practice: Logically, modeling is followed by students' actually using the strategies in language tasks. Practice should be graded, so students can practice the strategies in easy materials and, with time, they can be made to use them in more complicated materials and tasks. This sort of grading is recommended by Deshler, Alley, Warner and Shumaker (Salvia \& Hughes, 1990: 245).

\subsection{The Effect of CS Instruction on FL Speaking Proficiency}

According to Dornyei and Thurrell (1994: 44), the use of CSs is of special importance to language learners as they "provide them with a sense of security in the language by allowing extra time and room to maneuver." Emphasizing the importance of CSs, Oxford (1990: 49) maintains that learners who can use such strategies "sometimes communicate better than learners who know many more words and structures." A big body of empirical research in several L2 and FL settings has documented the positive impact of CS training on various aspects of speaking proficiency. Here are just very few examples of such studies. Nakatani (2005) taught 28 EFL learners some CSs. Compared to a control group $(\mathrm{N}=34)$ that received only the communicative course with no explicit focus on CSs, the strategy training group significantly improved oral proficiency test scores. The results of the transcription and retrospective protocol data analyses confirmed that participants' improved fluency and negotiation of meaning were partly due to an increased general awareness of CSs and to the use of specific CSs. Tavakoli, Dastjerdi and Esteki (2011) examined the effects of CS instruction on 40 Iranian intermediate EFL learners' oral production with regard to complexity, accuracy, and fluency. The experimental group received 8 lessons on strategies whereas the control group did not. The findings revealed that learners' oral performance improved in complexity, accuracy, and fluency.

Teng (2012) taught Cs to 24 English majors at a university in northern Taiwan 15 weeks. Instruction improved communication strategy use and communicative effectiveness of the 
learners who received training. Rababah (2016) examined the effect of CS instruction on EFL learners' oral communicative ability and their strategic competence. The strategy training group $(n=44)$ received CS training over 14 weeks, whereas the control group $(n=36)$ received only the normal communicative course with no explicit focus on CSs. The communication strategies targeted included circumlocution, appeal for help, asking for repetition, clarification request, confirmation request, self-repair, and guessing. Participants in the strategy training group significantly outperformed the control group in IELTS speaking test scores. They also used more CSs. In a study by Jabbari and Ardekani (2017), 60 Iranian intermediate EFL learners received explicit instruction of CSs. Those students outperformed a control group whose training did not include CS instruction in speaking proficiency.

\subsection{Aspects of Speaking Proficiency Assessed in the Present Study}

Aspects of speaking proficiency assessed in the present study included fluency and amount of speech. Accuracy was not included because what mattered was the flow of speech, rather than its accuracy. Crystal (1987: 421) defines fluency as "smooth, rapid, effortless use of language". Richards' (1990: 75) maintains that fluency means producing discourse that is comprehensible, easy to follow and free from breakdowns in communication. In Parrott's (1993: 197) point of view, fluency involves the ability to construct coherent utterances and stretches of speech, to respond and to speak without undue hesitation. In general, speed and effortlessness seem to be the two main characteristics of fluent speech. Speed (the amount of speech in a given time) and hesitation which is also related to speed can be measured quantitatively or qualitatively, whereas features like smoothness, ease and effortlessness are qualitative judgments, often based on a global impression (Chambers, 1997: 535). Many researchers assert that even variables like speed and pauses need qualitative judgments, and that they cannot simply be quantified and used to evaluate fluency. Chafe (1985), for example, considers it erroneous to just count pauses and evaluate fluency negatively on the basis of the number or length of pauses because pauses, in his point of view, are natural. Chambers (1997) concur with Chafe in this point. According to these researchers, speaking is a creative act that relates thought and language. Relating thought and language requires adjustments and readjustments. To conclude, some aspects of fluency, temporal variables, render themselves to quantitative evaluation (e.g. speed). Other aspects (e.g., smoothness) need qualitative evaluation. These two types of evaluation are not mutually exclusive, i.e., the two can be combined if this is perceived to give a clearer idea about students' oral fluency. This is the case in the present study. Two aspects of fluency, speed and coherence, will be judged by raters based on global impression making use of a rating scale. Amount of speech will be quantified.

\subsection{The Effect of CS Instruction on FL Speaking Self-efficacy}

Speaking is said to be associated with the highest level of anxiety of all language skills (Young, 1986; Kitano, 2001) to the extent that anxiety over speaking soon comes to mind whenever the expression language anxiety is mentioned. Young (1992) interviewed four distinguished language teaching specialists -Krashen, Hadley, Terrell and Rardin- and asked them about the skill they thought produced the highest level of anxiety. They all agreed on 
speaking as the most anxiety provoking of all the language skills. Research confirmed this theoretical claim. In a study by Horwitz, Horwitz and Cope (1986), students expressed more anxiety over speaking than any other language skill. Koch and Terrell (1991) and Young (1991) reported that speaking-oriented activities received higher anxiety ratings than any other in-class activities. Students interviewed by Price (1991) reported feeling anguished when compelled to speak publicly in the FL.

Based on self-efficacy literature, speaking self-efficacy can be said to refer to the learner's belief in their ability to succeed in oral communication via the FL. Mastery of CSs can enhance self-efficacy over speaking because they enable the learner to maneuver in the face of difficulties that may arise during the communication act. A learner who is aware that $\mathrm{s} / \mathrm{he}$ has a repertoire of strategies that $\mathrm{s} /$ he can use productively is expected to be more efficacious over speaking the FL compared to a learner who lacks such strategies. For this reason researchers support CS instruction that contributes to learners" "security, self-confidence, and motivation to communicate" (Manchon, 2000: 20). Some studies reported positive effects of CS instruction on speaking anxiety/self-efficacy. Majd and Iran (2014) taught 40 Iranian EFL learners how to use CSs in a treatment that lasted for 3 months. Learners who received the treatment improved their communication skills, increased their motivation and decreased their anxiety. Mesgarshahr and Abdollahzadeh (2014) investigated the impact of CSs on Iranian EFL learners' willingness to communicate. Control group students underwent regular language instruction, while the experimental group received CS. The results showed that the degree of willingness to communicate of the treatment group was significantly higher than that of the control group. However, strategy use did not relate to their of self-efficacy in a study conducted by Mutlu, Andarab and Karacan (2019) to explore the relationship between Turkish EFL learners' self-efficacy level and their opinion regarding their use of CSs. This hints to the need to further explore the relationship between CS use and self-efficacy over speaking.

\section{Method}

\subsection{Participants}

Two intact classes of EFL freshmen at Thadiq Sciences and Humanities College, Shaqra University, KSA participated in the study. They were enrolled in the Listening and Speaking 2 Course (Eng 122). In this course, students are trained on listening and speaking based on the tapestry textbook. Mainly they listen to audio material, answer comprehension questions and speak about a topic relevant to the listening material. No training on CSs is offered. All the participants were males (for there is segregation in Saudi universities). Their average age was 18.5 years. They had the same language experience in terms of years of study and rate of exposure to the language. The two classes were randomly assigned to an experimental group $(\mathrm{N}=20)$ and a control group $(\mathrm{N}=19)$.

\subsection{Instruments}

\subsubsection{The Speaking Test}

Two equivalent tests were developed to measure participants' speaking proficiency and CS 
use. Form A was used for pretesting and form B for Posttesting. The reason for using two forms was to avoid the effect of the first application on the second application in case one form is used. The test consisted of four warm up questions (not included in assessment) and two main questions: narration and opinion defending. In the narration question students were shown a sequence of four pictures. They were asked to examine the sequence for a minute and tell the story depicted in it. In the opinion defending question they were given an issue and asked to prepare for a minute and express their opinion regarding it, mentioning as many reasons as they could (e.g., some people believe that life in a big city is bad, others believe it is good. What is your opinion? Why). Students were told they could ask the interviewer (the researcher) for help when answering questions. A 4-point scale (from 1 to 4) was developed and used to rate students' responses in terms of speed and compressibility (adapted from Kassem, 2018), coherence, and self-efficacy. The result of the self-efficacy descriptor would be used in combination with the results of the self-report questionnaire of self-efficacy. This was thought to make assessment of speaking self-efficacy more reliable. Amount of speech, another aspect of speaking proficiency assessed in the present study, was quantified by counting the number of content words produced by the student. The reason for including amount of speech is that a student could get a good evaluation in speed although he produced only a small number of words. By the same token, a student could get a low score in speed in spite of producing an extended piece of speech.

The speaking test (along with the rating scale) was validated by four TEFL specialists who were invited to judge (1) if the two forms of the test are equivalent, (2) if the test could elicit sufficient speech samples from the students, (3) if students' speech products in response to test questions could be used to assess their speaking proficiency and CS use, and (4) if the rating scale was clear and appropriate. The test was then piloted on three students to identify if the pictures used were expressive and urging. Another aim was to identify the appropriate way to administer the test and establish a kind of rapport with respondents. Those two procedures helped to establish the validity of the speaking test.

To establish the reliability of the assessment of students' speaking proficiency, it was administered to 12 students rather than the students who participated in the study. Students' responses were assessed by two raters (assistant professors in the same college) based on the rating scale developed by the researcher. Raters therefore attended the interviews and assessed students independently. The scores given by the two raters were then correlated to establish inter-rater reliability. The total correlation coefficient between their scores was .84, which indicated good reliability.

\subsubsection{The Self-Efficacy Questionnaire}

A self-report questionnaire was developed to assess students' speaking self-efficacy beliefs. Relevant literature on self-efficacy and anxiety questionnaires (Horwitz, Horwitz and Cope, 1986; Henk \& Melnick, 1995; Nezami, Schwarzer, \& Jerusalem, 1996; Jinks \& Morgan, 1999; Seeger, 2009; Rahimi \& Abedini, 2009) helped the researcher in developing the items of the questionnaire used in the present study. Items were adapted or developed around three of the four dimensions of self-efficacy included in the Reader Self-Perception Questionnaire 
(SPRS) developed by Henk and Melnick (1995: 472): (1) Progress: how one's perception of present performance compares with past performance, (2) Observational comparison: how one perceives own performance compared with the performance of others, and (3) Physiological States: internal feelings that one experiences when performing. Some items were also developed to grope students' use of oral communication strategies.

The questionnaire that initially included 32 items was content validated by four EFL professors to decide on its validity for probing EFL student speaking self-efficacy perceptions. Based on the recommendations of the jury, some items were either reworded or deleted. The questionnaire was then pilotted on 21 students (rather than those who participated in the main experiment) to check its internal consistency. A factor analysis with Varimox rotation and eigenvalues of $\geq 1$ was conducted on the responses of the pilot sample) to decide on the items to be included in the final version of the questionnaire. Items with factor loadings less than 4 or those that loaded significantly on more than one factor were deleted and the correlation matrix was reanalyzed. A four factor solution was found, which accounted for $62 \%$ of the total variance in self-efficacy beliefs. Three factors were the same as the SPRS: progress (7 Items), observational comparison (5 items) and psychological states ( 7 items). Examining the content of items that loaded onto the fourth factor resulted in labeling it strategic awareness (4 items). The alpha estimate of internal consistency for the whole questionnaire was .92 .

The final form of the questionnaire thus consisted of 23 items. The summated rating method was used in scoring the questionnaire. Participants were asked to respond to items by indicating how far they agreed to the statements on a five-point rating scale. Each response was associated with a point value, where "Strongly agree" was assigned a point value of 5 and the response "Strongly disagree" a point value of 1 . Items with negative statement were reverse coded so that higher scores indicated higher self-efficacy. An individual's score in the questionnaire is the total of all the items.

\subsubsection{The Strategy Use Checklist}

A checklist was developed to record CS occurrences. The checklist had four headings with two columns each: a heading for each of the study's target CS with two columns labeled 'Used Effectively' and 'Used Ineffectively'. The two raters and the researcher were to put a tick in the appropriate place if the student used a CS effectively or ineffectively. Only effectively used CSs were used in statistical analysis. A CS was considered effective if two of the three raters agreed on its being effective. The effectively used CSs were used for (1) comparison between the two groups in general CS use and (2) correlation between CS use on one part and speaking proficiency and speaking self-efficacy on the other.

\subsection{Pretesting}

Before the treatment, form A of the speaking test and the speaking self-efficacy questionnaire were applied. All participants completed the self-efficacy questionnaire in one session. Students were then interviewed individually. The researcher interviewed students and raters assessed their speaking proficiency and jotted down instances of CSs using the rating scale and the strategy use checklist. As mentioned earlier, for an occurrence to be considered a CS, 


\section{Mll Macrothink}

it had to be considered an effective Cs by two of the three raters. Ineffective occurrences of CSs were excluded.

In order to make sure the two groups were homogeneous prior to the treatment in CS use, an independent-samples t-test was performed to compare the mean scores of the two groups in the four CSs. The resulting t-values indicated that the two groups were homogeneous before the treatment concerning individual CSs and total CS use. This is illustrated in table 1.

Table 1. Means, standard deviations and t-values for the pretest mean differences between the two groups on CS use

\begin{tabular}{|c|c|c|c|c|c|c|}
\hline Test & Group & $\mathrm{M}$ & SD & $\mathrm{df}$ & t-value & Sig. \\
\hline \multirow{2}{*}{ Circumlocution } & Exp. & .333 & .488 & \multirow[t]{2}{*}{28} & \multirow[t]{2}{*}{.386} & \multirow[t]{2}{*}{.702} \\
\hline & Cont. & .267 & .458 & & & \\
\hline \multirow{2}{*}{ Approximation } & Exp. & .667 & .488 & \multirow[b]{2}{*}{28} & \multirow[b]{2}{*}{.336} & \multirow[b]{2}{*}{.739} \\
\hline & Cont. & .733 & .593 & & & \\
\hline \multirow{2}{*}{ Appeal for help } & Exp. & .400 & .507 & \multirow[t]{2}{*}{28} & \multirow[t]{2}{*}{.367} & \multirow[t]{2}{*}{.716} \\
\hline & Cont. & .333 & .488 & & & \\
\hline \multirow{2}{*}{ Use of fillers } & Exp. & .267 & .458 & \multirow[b]{2}{*}{28} & \multirow[b]{2}{*}{.756} & \multirow[b]{2}{*}{.456} \\
\hline & Cont. & .400 & .507 & & & \\
\hline \multirow{2}{*}{ Total } & Exp. & 1.67 & 1.11 & \multirow[b]{2}{*}{28} & \multirow[b]{2}{*}{.156} & \multirow[b]{2}{*}{.877} \\
\hline & Cont. & 1.73 & 1.22 & & & \\
\hline
\end{tabular}

Inter-rater correlations for speed and comprehensibility, coherence, self-efficacy, and total speaking proficiency were $.84, .86, .73$, and .93 respectively (all significant at the .01 level). This high agreement meant that the two raters were quite consistent with how they assessed students' speaking proficiency. An independent-samples t-test was then performed to compare the mean scores of the two groups on speaking proficiency. The resulting t-values indicated that the two groups were homogeneous before the treatment concerning the individual proficiency descriptors and total proficiency. Table 2 below shows this statistics.

Table 2. Means, standard deviations and t-values for the pretest mean differences between the two groups on speaking proficiency

\begin{tabular}{|c|c|c|c|c|c|c|}
\hline Test & Group & $\mathrm{M}$ & SD & df & t-value & Sig. \\
\hline \multirow{2}{*}{ Speed \& compressibility } & Exp. & 1.67 & .587 & 28 & \multirow[t]{2}{*}{1.531} & \multirow[t]{2}{*}{.137} \\
\hline & Cont. & 1.37 & .480 & & & \\
\hline \multirow{2}{*}{ Coherence } & Exp. & 1.50 & .500 & & \multirow[b]{2}{*}{1.146} & \multirow[b]{2}{*}{.262} \\
\hline & Cont. & 1.30 & .455 & 28 & & \\
\hline \multirow{2}{*}{ Self-efficacy } & Exp. & 1.40 & .470 & & \multirow[b]{2}{*}{.384} & \multirow[b]{2}{*}{.704} \\
\hline & Cont. & 1.47 & .480 & 28 & & \\
\hline \multirow{2}{*}{ Total } & Exp. & 1.52 & .398 & 28 & \multirow[t]{2}{*}{.985} & \multirow[t]{2}{*}{.333} \\
\hline & Cont. & 1.38 & .405 & & & \\
\hline \multirow{2}{*}{ Amount of speech } & Exp. & 72.20 & 7.63 & & \multirow[b]{2}{*}{.066} & \multirow[b]{2}{*}{.948} \\
\hline & Cont. & 72.40 & 8.89 & 28 & & \\
\hline
\end{tabular}


The resulting t-values also indicated the homogeneity of the two groups in speaking self-efficacy before the treatment. (The speaking self-efficacy pretest yielded an alpha reliability estimate of .89 , which is quite high). This data is presented in table 3 .

Table 3. Means, standard deviations and t-values for the pretest mean differences between the two groups on speaking self-efficacy

\begin{tabular}{|l|l|l|l|l|l|l|}
\hline Test & Group & M & SD & df & t-value & Sig. \\
\hline \multirow{2}{*}{ Speaking self-efficacy } & Exp. & 55.10 & 5.91 & & & \\
\cline { 2 - 4 } & Cont. & 56.42 & 5.82 & 37 & \multirow{2}{*}{-.703} & .487 \\
\hline
\end{tabular}

\subsection{The Treatment}

The treatment was implemented in the first semester of the academic year 2018-2019 in the Listening and Speaking 2 Course (Eng 122) that is allocated 2 hours a week. The control group was taught according to the steps of the tapestry textbook. They listened to tapes and did listening comprehension tasks (in the first hour) and talked about a topic relevant to the listening material (in the second hour). The treatment group received the same training with training in CSs included in the second hour allocated for speaking. Training was implemented in steps that are common to all direct teaching models. First, students were given an idea about the strategy: what it is, when it can be used and why it is useful. Second, the researcher modeled the strategy for students. The researcher gave examples of situations where he had to use CSs while thinking aloud so students could see the utility of the target strategy. Students were then guided by the researcher to use the target CSs. Students were taught a CS in the first 30 minutes and then were guided in using it in the speaking activity during the second 30 minutes. This procedure was repeated two times for each of the four target CSs (8 classes). For the remaining classes ( 5 classes), students did the speaking activity that lasted for an hour and implemented the taught CSs. The researcher used to remind students to use CSs and jotted down the strategies they used. Every time a student used a strategy the researcher emphasized and recognized it.

The researcher gave students several examples to model the use of CSs (e.g., circumlocution: policemen serve their country by arresting people who do bad things like stealing for criminals; approximation: after buying something you should ask the salesperson to give you a paper of the money you pay for receipt). Besides, several activities were used to train students on (1) circumlocution: 'Stuff in a Sack' and 'A circumlocution Game' (Salomone \& Marsal, 1997), (2) approximation: 'Use Similar Words' developed by the researcher, (3) appeal for help: 'Elicit the Word from the Communication Partner' developed by the researcher, and (4) fillers: Adding Fillers (Dornyei, 1995) and One-Word-Dialogues (Dornyei $\&$ Thurrell, 1991). To describe just one example activity, in the stuff in a sack activity the researcher wrote words, both concrete and abstract, in the students' first language, on small cards and put cards in a paper bag. The bag was placed on a desk in front of the classroom and students, one by one, came forward and picked cards which they were to define in English without using any parts of the words. Furthermore, students were provided with a list of (1) common linguistic devices which are used in circumlocution (e.g., 'the instrument which is used for...') and (2) common fillers (e.g., as a matter of fact, to be honest). Mastery 
of such devices enhances the students' ability to use CSs (Dornyei, 1995).

\subsection{Posttesting}

After the treatment, participants completed the self-efficacy questionnaire and took form B of the speaking test. Alpha estimate for the internal consistency of the self-efficacy questionnaire was .87. Inter-rater correlations for speed and comprehensibility, coherence, self-efficacy, and total speaking proficiency were $.80, .83, .80$, and .94 respectively (all significant at the .01 level). The independent-samples t-test was then used to explore the differences between the groups in CS use, speaking proficiency and speaking self-efficacy.

\section{Results}

\subsection{The Effect of CS Training on CS Use}

Significant differences were found between the two groups in three of the four CSs and total CS use in favor of the treatment group. More specifically, at the end of the experiment, the treatment group outperformed the control group in circumlocution $(\mathrm{t}(28)=4.54, \mathrm{p}=.000)$, approximation $(\mathrm{t}(28)=2.78, \mathrm{p}=.010)$, fillers $(\mathrm{t}(28)=6.77, \mathrm{p}=.000)$, and total CS use $(\mathrm{t}$ $(28)=7.46, \mathrm{p}=.000)$. The two groups did not differ significantly in appeal for help $(\mathrm{t}(28)=$ $1.69, \mathrm{p}=.101)$. These results are summarized in Table 4 below.

Table 4. Means, standard deviations and t-values for the posttest mean differences between the two groups on CS use

\begin{tabular}{|l|l|l|l|l|l|l|}
\hline Test & Group & $\mathrm{M}$ & $\mathrm{SD}$ & $\mathrm{df}$ & t-value & Sig. \\
\hline \multirow{2}{*}{ Circumlocution } & Exp. & 1.73 & .704 & 28 & 4.54 & $\mathbf{. 0 0 0}$ \\
\cline { 2 - 6 } Approximation & Cont. & .533 & .743 & & & \\
\hline \multirow{3}{*}{ Appeal for help } & Exp. & 1.33 & .488 & 28 & 2.78 & $\mathbf{. 0 1 0}$ \\
\cline { 2 - 6 } & Cont. & .800 & .561 & & & \\
\hline \multirow{2}{*}{ Use of fillers } & Exp. & .533 & .640 & 28 & \multirow{2}{*}{1.69} & .101 \\
\cline { 2 - 5 } & Cont. & .200 & .414 & & & \\
\hline \multirow{2}{*}{ Total } & Exp. & 1.80 & .561 & 28 & \multirow{2}{*}{6.77} & $\mathbf{. 0 0 0}$ \\
\cline { 2 - 5 } & Cont. & .467 & .516 & & & \\
\hline
\end{tabular}

\subsection{The Effect of CS Training on Speaking Proficiency}

Significant differences were found between the two groups in two of the three descriptors of speaking proficiency, total speaking proficiency and amount of speech in favor of the treatment group. More specifically, at the end of the experiment, the treatment group outperformed the control group in speed and comprehensibility $(\mathrm{t}(28)=2.11, \mathrm{p}=.044)$, speaking self-efficacy $(\mathrm{t}(28)=3.11, \mathrm{p}=.004)$, total speaking proficiency $(\mathrm{t}(28)=2.05, \mathrm{p}$ $=.049)$, and amount of speech $(\mathrm{t}(28)=7.46, \mathrm{p}=.000)$. The two groups did not differ significantly in coherence $(\mathrm{t}(28)=.299, \mathrm{p}=.767)$. These results are summarized in Table 5 below. 
Table 5. Means, standard deviations and t-values for the posttest mean differences between the two groups on speaking proficiency

\begin{tabular}{|c|c|c|c|c|c|c|}
\hline Test & Group & M & SD & df & t-value & Sig. \\
\hline \multirow{2}{*}{ Speed \& compressibility } & Exp. & 2.00 & .655 & 28 & \multirow[t]{2}{*}{2.11} & \multirow[t]{2}{*}{.044} \\
\hline & Cont. & 1.53 & .550 & & & \\
\hline \multirow{2}{*}{ Coherence } & Exp. & 1.50 & .598 & 28 & \multirow[t]{2}{*}{.299} & \multirow[t]{2}{*}{.767} \\
\hline & Cont. & 1.43 & .623 & & & \\
\hline \multirow{2}{*}{ Self-efficacy (rating) } & Exp. & 2.03 & .441 & 28 & \multirow[t]{2}{*}{3.11} & \multirow[t]{2}{*}{.004} \\
\hline & Cont. & 1.47 & .550 & & & \\
\hline \multirow{2}{*}{ Total } & Exp. & 1.94 & .510 & 28 & \multirow[t]{2}{*}{2.05} & \multirow[t]{2}{*}{.049} \\
\hline & Cont. & 1.48 & .511 & & & \\
\hline \multirow{2}{*}{ Amount of speech } & Exp. & 90.67 & 8.62 & 28 & \multirow[t]{2}{*}{5.6} & \multirow[t]{2}{*}{.000} \\
\hline & Cont. & 71.93 & 9.56 & & & \\
\hline
\end{tabular}

\subsection{The Effect of CS Training on Speaking Self-efficacy}

A significant difference was found between the two groups ( $t(37)=2.50, \mathrm{p}=.017$ ) in speaking self-efficacy (as measured by the self-report questionnaire) after the treatment in favor of the treatment group. This statistics is presented in table 6 .

Table 6. Means, standard deviations and t-values for the posttest mean differences between the two groups on speaking self-efficacy

\begin{tabular}{|l|l|l|l|l|l|l|}
\hline Test & Group & $\mathrm{M}$ & SD & df & t-value & Sig. \\
\hline \multirow{2}{*}{ Speaking self-efficacy } & Exp. & 61.79 & 7.00 & 37 & 2.50 & $\mathbf{. 0 1 7}$ \\
\cline { 2 - 7 } & Cont. & 56.75 & 5.50 & & & \\
\hline
\end{tabular}

To get an idea about the gains students in the two groups attained from pre- to post-testing, paired-samples t-tests were performed on students' scores on the pretests and the posttests. Table 7 below includes data concerning the comparison between CS use, speaking proficiency and speaking self-efficacy of the treatment group before and after the treatment.

Table 7. Paired samples t- test for the treatment group pre- and posttests

\begin{tabular}{|l|l|l|l|l|l|l|}
\hline Test & $\mathrm{M}$ & $\mathrm{SD}$ & $\mathrm{SEM}$ & $\mathrm{t}$ & $\mathrm{df}$ & Sig. (2-tailed) \\
\hline CS use & -3.73 & 1.22 & .315 & -11.82 & 14 & $\mathbf{. 0 0 0}$ \\
\hline Speed \& comprehensibility & -.333 & .523 & .135 & -2.47 & 14 & $\mathbf{. 0 2 7}$ \\
\hline Coherence & .000 & .627 & .162 & .000 & 14 & 1.00 \\
\hline Self-efficacy (rating) & -.633 & .480 & .124 & -5.10 & 14 & $\mathbf{. 0 0 0}$ \\
\hline Total & -.322 & .465 & .120 & -2.68 & 14 & $\mathbf{. 0 1 8}$ \\
\hline Amount of speech & -18.47 & 6.70 & 1.57 & -11.78 & 14 & $\mathbf{. 0 0 0}$ \\
\hline $\begin{array}{l}\text { Self-efficacy } \\
\text { (questionnaire) }\end{array}$ & -7.13 & 4.98 & 1.29 & -5.53 & 14 & $\mathbf{. 0 0 0}$ \\
\hline
\end{tabular}

It is clear from table 7 that the treatment group achieved significantly better on the posttests of CS use $(\mathrm{t}(14)=-11.82, \mathrm{p}=.000)$, speed and compressibility $(\mathrm{t}(14)=-11.82, \mathrm{p}=.000)$, 
self-efficacy as measured by raters $(\mathrm{t}(14)=-5.10, \mathrm{p}=.000)$, total speaking proficiency $(\mathrm{t}(14)$ $=-2.68, \mathrm{p}=.018)$, amount of speech $(\mathrm{t}(14)=-11.78, \mathrm{p}=.000)$, and self-efficacy as measured by the questionnaire $(\mathrm{t}(14)=-5.53, \mathrm{p}=.000)$. The only descriptor of speaking proficiency that the treatment group did not improve significantly after the treatment was coherence.

Table 8 below presents data concerning the comparison between CS use, speaking proficiency and speaking self-efficacy of the control group before and after the treatment.

Table 8. Paired samples t- test for the control group pre- and posttests

\begin{tabular}{|l|l|l|l|l|l|l|}
\hline Test & $\mathrm{M}$ & $\mathrm{SD}$ & $\mathrm{SEM}$ & $\mathrm{t}$ & $\mathrm{df}$ & Sig. (2-tailed) \\
\hline CS use & -.267 & 1.099 & .284 & -.939 & 14 & .364 \\
\hline Speed \& comprehensibility & -.167 & .362 & .093 & -1.78 & 14 & .096 \\
\hline Coherence & -.133 & .352 & .091 & -1.47 & 14 & .164 \\
\hline Self-efficacy (Rating) & .000 & .189 & .049 & .000 & 14 & 1.00 \\
\hline Total & -.100 & .187 & .048 & -2.13 & 14 & $\mathbf{. 0 4 7}$ \\
\hline Amount of speech & .467 & 4.31 & 1.11 & .420 & 14 & .681 \\
\hline $\begin{array}{l}\text { Self-efficacy } \\
\text { (Questionnaire) }\end{array}$ & -.533 & 1.41 & .363 & -1.49 & 14 & .164 \\
\hline
\end{tabular}

Table 8 shows that the control group improved significantly in only total speaking proficiency $(\mathrm{t}(14)=-2.13, \mathrm{p}=.047)$. They showed no significant improvement in speed and compressibility, coherence, self-efficacy as measured by raters, amount of speech and self-efficacy as measure by the questionnaire.

In order to attribute the improvement that the treatment group achieved in all dependent variables (except coherence), Pearson correlations were computed as shown in table 9 below.

Table 9. Correlations between CSs and speaking proficiency and self-efficacy

\begin{tabular}{|l|l|l|}
\hline \multirow{5}{*}{ Speed \& comprehensibility } \\
\cline { 2 - 3 } & Pearson Correlation & $\mathbf{. 5 8 3}(*)$ \\
Sig. (2-tailed) & .023 \\
& N & 15 \\
\cline { 2 - 3 } CSs & Coherence & \\
& Pearson Correlation & $\mathbf{. 5 9 6}(*)$ \\
& Sig. (2-tailed) & .019 \\
& N & 15 \\
\cline { 2 - 3 } & Self-efficacy (rating) & \\
& Pearson Correlation & $\mathbf{. 6 1 0}(*)$ \\
& Sig. (2-tailed) & .016 \\
& N & 15 \\
\cline { 2 - 3 } & Total speaking proficiency & \\
& Pearson Correlation & $.659(* *)$ \\
& Sig. (2-tailed) & .008 \\
& N & 15 \\
\hline
\end{tabular}




\begin{tabular}{|l|l|l|}
\hline \hline & Amount of speech & $\mathbf{. 8 3 8}(* *)$ \\
& Pearson Correlation & .000 \\
& Sig. (2-tailed) & 15 \\
\hline N & \\
\cline { 2 - 3 } & Self-efficacy (questionnaire) & $\mathbf{7 8 2}(* *)$ \\
& Pearson Correlation & .000 \\
& Sig. (2-tailed) & 15 \\
\hline
\end{tabular}

It is obvious from table 9 that CSs correlated positively with all individual descriptors of speaking proficiency, total speaking proficiency, amount of speech and self-efficacy. It is therefore possible to attribute this significant improvement to CS training.

\section{Discussion}

With the exception of the appeal for help strategy of the treatment group whose mean increased from .4 to .53 but did not reach a significant level, CS training had significant positive effects on the three other CSs included in the study. This is consistent with the contention that CSs are teachable (e.g., Dornyei, 1995; Shrum \& Glisan, 2000; Maleki, 2010). It is also consistent with research findings (e.g., Salomone \& Marsal, 1997; Abdel Rehim, 2002; Kongsom, 2006; Al-Bzour \& Baniabdelrahman, 2017). A possible explanation why the treatment group did not significantly increase the use of appeal for help after treatment is the similarity between this strategy and circumlocution. Both strategies include defining the lacking word. It seems that it is easier for students to just define the lacking word in a statement than to define it in a question directed to the interlocutor. Why would a speaker say what do you call people who do bad things like stealing if they can just say people who do bad things like stealing in case of lacking the word criminal. Circumlocution therefore seems to be more readily usable. Students might have increased their use of appeal for help if training lasted for a longer time and if speaking activities and test tasks provided for interaction and negotiation of meaning. Anyway, the improvement that treatment group students achieved in CS use can be attributed to the training they received which included awareness raising, CS training activities and directed practice of CSs in the various speaking activities done throughout the course. Strategy training was the only difference between treatment offered to the treatment group and that offered to the control group. It is therefore quite safe to attribute changes in CS use to the proposed training.

With the exception of coherence, the treatment group outperformed the control group in four aspects of speaking proficiency, namely speed and comprehensibility, self-efficacy, amount of speech and total proficiency. This is in line with the findings of other studies in which CS training improved various aspects of EFL learners' speaking (e.g., Nakatani, 2005; Tavakoli, Dastjerdi and Esteki, 2011; Teng, 2012; Rababah, 2016; Jabbari and Ardekani, 2017). The improvement that treatment students achieved in speed and comprehensibility is logical. On average each student used circumlocution and approximation several times in the posttest. This way they could overcome shortage of vocabulary and continue their speech. Conversely, students in the control group stumbled over unknown vocabulary, so they used to hesitate and 
pause for long. Fillers also seemed to help students' flow of speech and gain them time to think about what to say next. This concurs with Taylor's statement (2002: 171) that fillers "facilitate the flow of conversation by giving the speaker time to organize his or her thoughts, maintain or relinquish the floor...".

By the same token CSs enabled treatment group students to overcome lack of vocabulary and give more extended pieces of speech in comparison with control group students. This same finding was reported in the studies by Nakatani (2005) and Saeidi and Farshchi (2015) where CS training increased trainees' amount of oral production. The only descriptor of speaking proficiency that treatment group students did not improve significantly after training was coherence. A possible explanation for this finding is that coherence needs direct teaching. That is, students need to be directly taught how to use cohesive devices to make their speech more cohesive. The improvement the control group students achieved in total speaking proficiency is not surprising. The students did the same speaking activities as the treatment group students. No doubt such activities had an effect on students' speaking proficiency. However, the CS element resulted in treatment students' achieving more significant increases not only in total speaking proficiency but also in individual descriptors of speaking proficiency.

Finally, participants who received CS training developed higher self-efficacy over speaking English as measured by raters and the self-report questionnaire in comparison with students who did not receive the proposed training. This concurs with the findings of studies that reported positive effects of CS training on EFL students' speaking anxiety/self-efficacy (e.g., Majd \& Iran, 2014; Mesgarshahr \& Abdollahzadeh, 2014). Students who have in their repertoire strategies that they can use whenever facing communication difficulties are more likely to be more self-efficacious about their communication ability than students lacking such strategies. This is asserted by Manchon (2000: 20) who suggested that CS instruction contributes to learners" "security, self-confidence, and motivation to communicate". According to Dornyei and Thurrell (1994: 44), the use of CSs is of special importance to language learners as they "provide them with a sense of security in the language by allowing extra time and room to maneuver."

\section{Conclusion and Implications}

Explicit teaching of CSs in the present study improved CS use, speaking proficiency and speaking self-efficacy. This is of particular significance for Saudi EFL students who, as supported by a big body of research (e.g., Al-Ghamari, 2004; Rababah, 2005; Fageeh, 2011; Alyan, 2013; Al-Nasser, 2015; Kassem, 2018), face many difficulties relevant to speaking English as a FL. Training those students on CSs can make a big difference in their EFL speaking. It is, therefore, recommended that such training be integrated in speaking courses offered to those students. Also, it is recommended that CS training be integrated in the curricula of prospective teachers of EFL at colleges of education, so they can train students on CSs when they are full teachers. It is highly desirable that EFL students begin their university study with effective CSs in their repertoire. 


\section{References}

Abdel Rehim, A. R. (2002). The effect of communication strategies and risk taking on oral fluency. Occasional Papers in the Development of English Language Education, 33, 181-232.

Al-Ghamari, T. (2004). Integrating writing with other skills. Muscat Message, 78- 81.

Al-Nasser, A. S. (2015). Problems of English Language Acquisition in Saudi Arabia: An Exploratory-cum-remedial Study. Theory and Practice in Language Studies, 5(8), 1612-1619.

Alyan, A. (2013). Oral Communication Problems Encountering English Major Students: Perspectives of Learners and Teachers in Palestinian EFL University Context. AWEJ, 4(3), 226-238.

Bataineh, R., Al-Bzour, W. \& Baniabdelrahman, A. (2017). On the teachability of communication strategies to Jordanian EFL beginners: exploration and reflection. International Online Journal of Education and Teaching (IOJET), 4(3), 213-227.

Bialystok, E. (1990). Communication strategies. Oxford, UK: Basil Blackwell.

Canale, M., \& Swain, M. (1980). Theoretical bases of communicative approaches to second language teaching and testing. Applied Linguistics, 1(1), 1-47.

Chafe, W. (1985). Some reasons for hesitating. In D. Tannen and M. Saville-Troike (Eds.), perspectives on silence. Norwood, NJ: Ablex.

Chalmers, D. \& Fuller, R. (1996). Teaching for learning at university: theory and practice. Kogan Page.

Chambers, F. (1997). What do we mean by fluency? System, 25(4), 535-544.

Crystal, D. (1987). The Cambridge encyclopedia of language. Cambridge: Cambridge University Press.

de Bot, K. (1992). A bilingual production model: Levelt's 'speaking' model adapted. Applied Linguistics, 13, 1-24.

Dornyei, Z. \& Thurrell, S. (1991). Strategic competence and how to teach it. ELT Journal, 45, 16-23.

Dornyei, Z. (1995). On the teachability of communication strategies. TESOL Quarterly, 29(1), 55-85.

Dornyei, Z., \& Scott, M. L. (1997). Communication strategies in a second language: Definitions and taxonomies. Language Learning, 47(1), 173-210.

Færch, C., \& Kasper, G. (1983). Plans and strategies in foreign language communication. In C. Faerch \& G. Kasper (Eds.), Strategies in interlanguage communication. London: Longman.

Fageeh, A. I. (2011). EFL learners' use of blogging for developing writing skills and 
enhancing attitudes towards English learning: An exploratory study. Journal of Language and Literature, 2 (1), 31-48.

Faucette, P. (2001). A pedagogical perspective on communication strategies: Benefits of training and an analysis of English language teaching materials. Second Language Studies, 19(2), 1-40.

Griffiths, C. (2004). Language learning strategies theory and research. Crie.org.nzlresearch_paper/c_griffths.

Henk, W. A., \& Melnick, S. A. (1995). The Reader Self-Perception Scale (RSPS): A new tool for measuring how children feel about themselves as readers. The Reading Teacher, 48, 470-482.

Horwitz, E. K., Horwitz, M. B., \& Cope, J. (1986). Foreign language classroom anxiety. The Modern Language Journal, 70(2), 125-132.

Jabbari, M. \& Ardekani, F. (2017). The Effect of Explicit Teaching of Communicative Strategies on the Conversation Ability of Iranian EFL Learners. Imperial Journal of Interdisciplinary Research, 3(2), 928-935.

Jinks, J. \& Morgan, V. (1999). Children's perceived academic self-efficacy: An inventory scale. The Clearing House, 72 (4), 224-230

Kassem, M. A. (2018). Improving EFL Students' Speaking Proficiency and Motivation: A Hybrid Problem-based Learning Approach. Theory and Practice in Language Studies, 8(7), 848-859.

Kellerman, E. (1991). Compensatory strategies in second language research: A critique, a revision, and some (none) implications for the classroom. In R. Phillipson, E. Kellerman, L. Slinker, M. Sharwood Smith, and M. Swain (Eds). Foreign/second language pedagogy research: A communicative volume for Clause Faerch. Clevedon: Multilingual Matters, 142-161.

Kellerman, E. (1998). When words fail: from communication strategies to strategies for communication. In K. Malmkjaer \& J. Williams (Eds.), context in language learning and language understanding. Cambridge: Cambridge University Press.

Kitano, K. (2001). Anxiety in the college Japanese language classroom. The Modern Language Journal, 85(iv), 549-563.

Koch, S. \& Terrell, T. (1991). The effect of the national approach on the affective filter. In E. Horwitz \& D. Young (Eds.), language anxiety: anxiety reactions in foreign and second language learning and performance. New York: Prentice Hall.

Kongsom, T. (2016). The Impact of Teaching Communication Strategies on English Speaking of Engineering Undergraduates. PASAA, 51, 39-69.

Kouroago, P. (1993). Language learning strategies in input-poor environments. System, 12(2), 165-173. 


\section{Ml Macrothink}

Journal for the Study of English Linguistics

ISSN 2329-7034

2019, Vol. 7, No. 1

Levelt, W. \& Roelofs, A. \& Meyer, A. (2000). A theory of lexical access in speech production. Behavioral and Brain Sciences, 22(1), 1-38.

Littlemore, J. (2003). The communicative effectiveness of different types of communication strategy. System, 31(3), 331-347.

Macaro, E. (2001). Learning strategies in foreign and second language classrooms. London and New York: Continuum.

Majd, G. \& Iran, Z. (2014). Teaching communication strategies to EFL learners and its impact on anxiety level and motivation: A hindering or facilitating factor? English for Specific Purposes World, 42(15), 1-15.

Maleki, A. (2010). Techniques to teach communication strategies. Journal of Language Teaching and Research, 1(5), 640-646.

Manchon, R.M. (2000). Fostering the autonomous use of communication strategies in the foreign language classroom. Links \& Letters, 7, 13-27.

Mesgarshahr, A. \& Abdollahzadeh, E. (2014). The impact of teaching communication strategies on EFL learners' Willingness to Communicate. Studies in Second Language Learning and Teaching, 4(1), 51-76.

Mutlu, A., Andarab, M. \& Karacan, C. (2019). Self-Efficacy and the Use of Compensatory Strategies: A Study on EFL Learners. European Journal of Educational Research, 8(1), 249255.

Nakatani, Y. (2005). The effects of awareness-raising training on oral communication strategy use. The Modern Language Journal, 89, 76-91.

Nakatani, Y. (2006). Developing an Oral Communication Strategy Inventory. The Modern Language Journal, 90(ii), 151-168.

Nezami, E., Schwarzer, R., \& Jerusalem, M. (1996). Persian adaptation (Farsi) of the general self-efficacy scale. fuberlin.de/ health/persean.htm.

O’Malley M \& Chamot, A. (1990). Learning strategies in second language acquisition. New York: Cambridge University Press.

Oxford, R, Crookall, D., Cohen, A., Lavine, R., Nyikos M. \& Sutter, W. (1990). Strategy training for language learners: six situational case studies and a training model. Foreign Language Annals, 22(3), 197-216.

Oxford, R. (1990). Language learning strategies: What every teacher should know. Boston, MA: Heinle \& Heinle.

Parrott, M. (1993). Tasks for language teachers. Cambridge: Cambridge University Press.

Price, M. (1991). The subjective experience of foreign language anxiety: interview with highly anxious students. In E. Horwitz \& D. Young (Eds.), language anxiety: from theory and research to classroom implications. Englewood Cliffs, NJ: Prentice Hall. 
Rababah, G. (2005). Strategic competence in an ELT syllabus. International Journal of Applied Linguistics, 145, 145-166.

Rababah, G. (2016). The Effect of Communication Strategy Training on the Development of EFL Learners' Strategic Competence and Oral Communicative Ability. Journal of Psycholinguistic Research, 45(3), 625-651.

Rahimi, A. \& Abedini, A. (2009). The interface between EFL learners' self-efficacy concerning listening comprehension and listening proficiency. Novitas-ROYAL, 3(1), 14-28.

Raya, M. J. (1998). Training language learners to learn. In W. Gewebr, P. Faber, M. J. Raya \& A. J. Peck (Eds.), aspects of modern language teaching in Europe. Routledge.

Richards, J. C. (1990). Conversationally speaking: approaches to the teaching of conversation. In J. C. Richards (ed.), the language teaching matrix. Cambridge: Cambridge University Press

Richards, J. C. (2008). Teaching Listening and Speaking: from Theory to Practice. New York: Cambridge University Press.

Saeidi, M. \& Farshchi, E. (2015). The Effect of Communication Strategy Teaching on EFL Learners' Oral Production in Content-based Courses. Theory and Practice in Language Studies, 5(1), 71-78.

Salomone, A. \& Marsal, F. (1997). How to avoid language breakdown? Circumlocution! Foreign Language Annals, 30(4), 473-484.

Salvia, J. \& Hughes, C. (1990). Curriculum-based assessment: testing what is taught. Macmillan Publishing Company.

Seeger, V. N. (2009). Collaborative retrospective miscue analysis: a pathway to self-efficacy in reading. Unpublished Thesis. Available from krex.k-state.edu/dspace/bitstream/ handle/.../VictoriaSeeger2009.pdf.

Shrum, J. \& Glisan, E. (2000). Teacher's handbook: contextualized language instruction. Heinle \& Heinle.

Tarone, E. (1980). Communication strategies, foreigner talk and repair in interlanguage. Language Learning, 30, 417-431.

Tavakoli, M., Dastjerdi, H. \& Esteki, M. (2011). The Effect of Explicit Strategy Instruction on L2 Oral Production of Iranian Intermediate EFL Learners: Focusing on Accuracy, Fluency and Complexity. Journal of Language Teaching and Research, 2(5), 989-997.

Taylor, G. (2002). Teaching gambits: the effect of instruction and task variation on the use of conversation strategies by intermediate Spanish students. Foreign Language Annals, 35(2), 171-181.

Teng, H. (2012). A study on the teachability of EFL communication strategies. Procedia Social and Behavioral Sciences 46, 3566-3570. 


\section{Macrothink}

Journal for the Study of English Linguistics

ISSN 2329-7034 2019, Vol. 7, No. 1

Willems, G. M. (1987). Communication strategies and their significance in foreign language teaching. System, 15(3), 351-364.

Williams, J. (2006). Combining communication strategies and vocabulary development. The Internet TESL Journal, 12(2).

Young, D. J. (1986). The relationship between anxiety and foreign language oral proficiency ratings. Foreign Language Annals, 19(5), 439-445.

Young, D. J. (1991). Creating a low anxiety classroom environment: what does language anxiety research suggest? The Modern Language Journal, 75, 426-437.

Young, D. J. (1992). Language anxiety from the foreign language specialist's perspective: interviews with Krashen, Omaggio Hadley, Terrell and Rardin. Foreign Language Annals, 25(2), 157-173.

\section{Appendix (1)}

The Speaking Self-Efficacy Questionnaire

1. I can say that my confidence in speaking English is high.

2. Now I speak English better than I could before.

3. When I compare myself to other students in my class, I am a good speaker of English.

4. I can manage when I run out of words while speaking English.

5. My ability to express myself orally in English doesn't improve.

6. I am less confident in my speaking ability than other students.

7. While speaking in English, I get so nervous I cannot say my mind.

8. Speaking in English is easier for me now than it used to be.

9. Before we start a speaking activity in the English class, I don't think that I will do well.

10. It doesn't bother me to speak English in front of other students.

11. Now I can make myself more comprehensible when I speak in English than I could before.

12. I believe that I have the ability to deal with any problems that may arise while speaking in English.

13. I think I promote my speaking ability better than other classmates.

14. I do not feel I am a good speaker of English.

15. I believe that my speaking ability improves with time.

16. I feel calm when I speak in English.

17. I can use good strategies that help me to express myself when I speak in English.

18. I can participate in free discussions in English better than before.

19. I think I can make my speech more comprehensible than other students.

20. I know what strategies to use when I speak in English.

21. I can monitor my speaking performance better than before.

22. I always feel that the other students speak English better than I do.

23. I am afraid that the other students will laugh at me when I speak in the English class. 


\section{Macrothink}

Journal for the Study of English Linguistics

ISSN 2329-7034

2019, Vol. 7, No. 1

Appendix (2)

The Rating Scale

\begin{tabular}{|c|c|}
\hline Score & Descriptor \\
\hline & speed and compressibility \\
\hline 1 & $\begin{array}{l}\text { The student speaks very slowly; pauses are frequent and lengthy; breakdowns are } \\
\text { detected and hesitation impedes possible communication. }\end{array}$ \\
\hline 2 & $\begin{array}{l}\text { The student is often slow and incomplete sentences are used. However, the student } \\
\text { is able to process the speech. }\end{array}$ \\
\hline 3 & $\begin{array}{l}\text { The student' speech is almost smooth. However, some hesitation and repetition } \\
\text { may take place with little effect on the comprehensibility. }\end{array}$ \\
\hline \multirow[t]{2}{*}{4} & $\begin{array}{l}\text { The student speaks fluently and smoothly. He is able to develop speech } \\
\text { appropriately. Hesitation and reluctance are very few. }\end{array}$ \\
\hline & Coherence \\
\hline 1 & $\begin{array}{l}\text { Few sentences are properly interconnected, unclear explanation; difficult to follow } \\
\text { sequence }\end{array}$ \\
\hline 2 & $\begin{array}{l}\text { Some sentences are properly interconnected; explanation is moderately clear; } \\
\text { transitions are awkward. }\end{array}$ \\
\hline 3 & $\begin{array}{l}\text { A reasonable range of proper intersentential connectors; clear explanation; easy to } \\
\text { follow sequence. }\end{array}$ \\
\hline \multirow[t]{2}{*}{4} & Most of the sentences are well-interconnected; clear well-developed explanation. \\
\hline & Self-efficacy \\
\hline 1 & The student is almost inhibited \\
\hline 2 & The student seems moderately inhibited \\
\hline 3 & The student looks fairly self-efficacious \\
\hline 4 & The student appears to be very self-efficacious \\
\hline
\end{tabular}

\section{Copyright Disclaimer}

Copyright for this article is retained by the author(s), with first publication rights granted to the journal.

This is an open-access article distributed under the terms and conditions of the Creative Commons Attribution license (http://creativecommons.org/licenses/by/3.0/). 